\title{
OVARIAN MASS, SIZE AND NUMBER OF FOLLICLES IN POSTPARTURIENT EWES
}

\author{
J. DANKO \\ University of Veterinary Medicine, Košice, Slovak Republic \\ Received November 29, 1996 \\ Accepted June 17, 1997
}

\begin{abstract}
D a n k o J.: Ovarian Mass, Size and Number of Follicles in Postparturient Ewes. Acta vet. Brno 1997, 66: 71-74.

The aim of this study was to follow in more detail changes of the ovaries during physiological puerperium in ewes. Twenty Slovak Merino ewes aged 3-5 yr and lambed in February were included in the experiment. The groups of animals were slaughtered $(n=5)$ on d 1, 7, 17 and 24 postpartum. Their reproductive apparatus was excised immediately after slaughter, their ovaries were identified as ipsilateral at the pregnant uterine horn, and contralateral at the non-pregnant horn. All ovaries were weighed, and size and numbers of follicles were evaluated on the ovarian surface. Mass of contralateral ovaries ranged from $0.686 \pm 0.24$ to $0.985 \pm 0.32 \mathrm{~g}$ and mass of ipsilateral ones from $0.935 \pm 0.21$ to $1.025 \pm 0,45 \mathrm{~g}$. However, none of the changes in ovarian mass were significant. Only small structures were observed on $d 1$ and 7 postpartum when evaluating follicle size. Highest number of follicles in both ovaries was found on 17 after parturition. These data provide further information on postparturient involutional and reparative processes of the reproductive apparatus in ewes.
\end{abstract}

Involution, postpartum, ovary, mass follicle

The ovaries are the primary target organ of reproduction apparatus in the gonadotropic hypothalamo-hypophyseal regulation of the reproductive cycle. Their morphological changes are dependent on the number of developing follicles with subsequent development of individual stages of the corpus luteum at the time of reproductive cycle, pregnancy, puerperium and lactation. The weight range for the sheep ovary reported by $\mathrm{H}$ a f e $\mathrm{z}$ (1974), McDonald (1980) is very variable and depends on the age of animals, breed, season, application of hormonal preparations (Kudláč and Vlček 1970; Whyman and Moore 1980; Krajničáková et al. 1992) and other factors acting during the whole reproductive cycle.

Literary studies about changes in the ovarian mass in postpartum of sheep are only sporadic. A decrease in the ovarian mass by $26 \%$ was recorded by B u rov (1982) on $\mathrm{d} 7$ after lambing. A non-significant decrease in mass of ovaries up to $\mathrm{d} 7$ postpartum was reported by Krajničáková et al. (1990) and Krajničáková et al. (1991) on d 7 postpartum. However, the mass of the ipsilateral ovary tended to surpass that of the contralateral ovary during the experimental period.

Observation concerning the inhibitory effect on the follicle growth from d 140 of pregnancy to $\mathrm{d} 5$ postpartum showed that the corpus luteum of the late pregnancy has a stimulating effect on development of the ovarian follicles during this period (A l g u b o ry and Martinet 1986).

Based upon the above-mentioned facts, the aim of our work was to determine the ovarian mass, size and number of follicles in ewes during observed intervals postpartum (p.p.). 


\section{Materials and Methods}

Twenty sheep aged 3-5 yr were used in the experiment. All animals lambed in February. They were slaughtered on $\mathrm{d} 1,7,17$ and 24 postpartum $(n=5)$. The reproductive organs were excised immediately after slaughter, and the mass of ovaries was determined using an analytical balance. Before evaluation, the ovaries were divided into the ipsilateral at the pregnant uterine horn, and contralateral ones at the non-pregnant horn. The size of follicles was measured using a micrometer dial calliper. After the mass of ovaries, size and number of follicles were determined, the ovaries were fixed for further histological examination. Statistical significance of ovarian mass was compared to that found on 11 postpartum. Student's t-test was used for calculation.

\section{Results}

The results of our study are shown in Table 1 . The mass of ipsilateral ovaries on $\mathrm{d} 1$ and 7 postpartum ranged from $0.935 \pm 0.21$ to $0.958 \pm 0.15 \mathrm{~g}$. In the remaining days of the experiment it slightly increased.

The mean mass of contralateral ovaries was lower in comparison with that of ipsilateral ones and it ranged from $0.686 \pm 0.24$ to $0.669 \pm 0.16 \mathrm{~g}$ on $\mathrm{d} 1$ and 7 post partum.

The observed mean mass, i.e. $0.985 \pm 0.32 \mathrm{~g}$ on $\mathrm{d} 17$ postpartum was similar to mean mass of ipsilateral ovaries on $\mathrm{d} 7$ postpartum.

Numbers and sizes of follicles are presented in Table 1, too. Follicles were divided into three groups with $2 \mathrm{~mm}, 4 \mathrm{~mm}$ and $5 \mathrm{~mm}$ in diameter. A certain stagnation of follicle growth was observed on $\mathrm{d} 1$ and 7 postpartum. In addition, small structures and remains of corpus luteum were observed on the ovarian surface on the same days.

Evaluating the number and size of follicles on $\mathrm{d} 17$ postpartum, 7 follicles were found on each ovary. On the ipsilateral ovary, 4 follicles were $2 \mathrm{~mm}$ in diameter, and 3 follicles had $4 \mathrm{~mm}$. On contralateral ovary 3 follicles attained the size of $2 \mathrm{~mm}, 1$ follicle $4 \mathrm{~mm}$ and 3 follicles was $5 \mathrm{~mm}$ in size.

On d 24 postpartum, 4 follicles were observed on the ipsilateral ovary. Three of them were $2 \mathrm{~mm}$ in diameter, and 1 follicle attained $5 \mathrm{~mm}$. Three follicles were present on the contralateral ovary, 2 of them were $2 \mathrm{~mm}$ large and 1 was $5 \mathrm{~mm}$. Neither ovulation occurred nor corpus luteum was detected during the whole period of experiment. None of the changes in ovarian mass were significant at any of the postpartal days studied.

Table 1

The ovarian mass, size and number of follicles in postparturient ewes

\begin{tabular}{|c|c|c|c|c|c|c|}
\hline \multirow[t]{2}{*}{$\begin{array}{l}\text { Day after } \\
\text { parturition }\end{array}$} & \multirow[t]{2}{*}{$\begin{array}{l}\text { Number of } \\
\text { animals }\end{array}$} & \multirow[t]{2}{*}{$\begin{array}{l}\text { Ovaries } \\
\text { mass }(\mathrm{g})\end{array}$} & \multicolumn{4}{|c|}{$\begin{array}{l}\text { Ipsilateral number } \\
\text { of follicles }\end{array}$} \\
\hline & & & $(2 \mathrm{~mm})$ & $(4 \mathrm{~mm})$ & $(5 \mathrm{~mm})$ & SS \\
\hline 1 & 5 & $0.935 \pm 0.21$ & - & - & - & 14 \\
\hline 7 & 5 & $0.958 \pm 0.15$ & - & - & - & 28 \\
\hline 17 & 5 & $1.025 \pm 0.45$ & 4 & 3 & - & 22 \\
\hline \multirow[t]{3}{*}{24} & 5 & $1.024 \pm 0.28$ & 3 & - & 1 & 15 \\
\hline & & $\begin{array}{l}\text { Ovaries } \\
\text { mass }(\mathrm{g})\end{array}$ & \multicolumn{4}{|c|}{$\begin{array}{c}\text { Contralateral number } \\
\text { of follicles }\end{array}$} \\
\hline & & & $(2 \mathrm{~mm})$ & $(4 \mathrm{~mm})$ & $(5 \mathrm{~mm})$ & SS \\
\hline & & $0.686 \pm 0.24$ & - & - & - & 16 \\
\hline & & $0.669 \pm 0.16$ & - & - & - & 23 \\
\hline & & $0.985 \pm 0.32$ & 3 & 1 & 3 & 20 \\
\hline & & $0.890 \pm 0.20$ & - & 2 & 1 & 14 \\
\hline
\end{tabular}

SS - small structures 


\section{Discussion}

The mass of the contralateral ovary was found to be non-significantly lower compared to that of the ipsilateral one after lambing. A decrease in the mass of the contralatral ovaries up to 7 after lambing is comparable with the data by Burov (1982) who reported a $26 \%$ decrease in the weight on the same day. If we consider that this variable is influenced by the number and size of follicles present on the ovary, then the ovarian mass found on $\mathrm{d} 17$ and 24 postpartum supports this conclusion.

Changes in the ovarian mass at the intervals employed in our study support indirectly the findings on the lowest concentrations of progesterone in the blood serum of sheep (Greyling and Van Derwesthuysen 1979; Krajničáková etal. 1994, 1995) as well as on higher levels of 17-beta estradiol and androgens, which are the symptoms of the follicular growth.

In the postparturient period, the follicles develop and grow to maturity, reaching the ovulation stage, or they become atretic, and disappear. Our results showed that during the first days after lambing the follicular growth was rather slow. Similar results obtained at the beginning of puerperium were reported by Duf ou r and R oy (1983). The interval from parturition to $\mathrm{d} 7$ postpartum is short and insufficient for the growth and development of preantral follicles. This may be connected with the previous pregnancy as reported by Algubory and Martinet (1986). The number of follicles found on 17 an 24 of our observation (Table 1) is comparable with findings of Daile y et al. (1982).

The results of our study extend the observation period for postparturient ovarian and follicular changes to the first month during which the involutional and reparative changes of the reproductive apparatus take place.

\section{Hmotnost' vaječníkov, počet a velkost folikulov u oviec po pôrode}

Cielom tejto práce bolo rozširit sledovanie hmotnosti vaječníkov, počet a velkost povrchových folikulov oviec pri fyziologickom priebehu puepéria. Do experimentu bolo zaradených 20 bahníc plemena Slovenské merino vo veku 3-5 rokov, ktoré sa obahnili vo februári. Zvieratá sme odporážali $(n=5)$ v 1., 7., 17. a 24. deň po pôrode. Bezprostredne po vykrvení sme ovciam excidovali pohlavný aparát a zistovali hmotnosí vaječníkov Vaječníky sme pred posúdením rozdelili na ipsi- a kontralaterálne. Na povrchu vaječníkov sme posudzovali velkost i počty folikulov. Hmotnost kontralaterálnych vaječníkov sa pohybovala $\mathrm{v}$ sledovanom období od $0,686 \pm 0,24$ do $0,985 \pm 0,32 \mathrm{~g}$ a hmotnost ipsilaterálnych od $0,935 \pm 0,21$ do $1,025 \pm 0,45 \mathrm{~g}$. Pri hodnotení velkosti folikulov, rozdelených do 3 skupín, sme v 1 . a 7 . dni po pôrode zaznamenali iba drobné štruktúry. V 17. dni sme pozorovali 7 folikulov na obidvoch vaječníkoch. Naše výsledky rozširujú poznatky o involučných a reparačných procesoch na ováriách oviec v prvom mesiaci po pôrode.

\section{References}

ALGUBORY, K. H., MARTINET, J. 1986: Comparison of the total ovarian follicular populations at day 140 of pregnancy and day 5 post partum in ewes. Theriogenology 25:795-808

BUROV, V. G. 1982: Involucija polovych organov u ovec. Veterinarija 2:57-58

DAILEY, R. A., FOGWELL, R. L.. THAYNE. W. V. 1982: Distribution of visible follicles on the ovarian surface in ewes. J. Anim. Sci. 54:1196-1204

DUFOUF, J. J., ROY, G. L. 1983: Distribution of ovarian follicular populations during early post partum in the dairy cows. J. Anim. Sci. 57: Suppl., pp. 331-336

GREYLING, J. P. C., VAN DERWESTHUYSEN, I. M. 1979: The synchronization of oestrus in sheep. 2. Dose effect of prostaglandin in the double injection regime. S. Afr. J. Anim. Sci. 9:193-195 
HAFEZ. E. S. E. 1974: Reproduction in farm animals. Philadelphia, Lea and Febiger

KRAJNIČÁKOVÁ, M., ELEČKO, J., BEKEOVÁ. E., MARAČEK, I., HENDRICHOVSKÝ, V. 1990: Biochemické parametre maternice vaječníkov a koncentrácie 17 beta-estradiolu $\left(\mathrm{E}_{2}\right)$ po pôrode oviec. Vet. Med. Praha 35:747-756

KRAJNIĆÁKOVÁ, M., ELEĆCKO, J., BEKEOVÁ, E., MARAČEK, I., HENDRICHOVSKÝ, V. 1991: Biometrické parametre maternice a vaječníkov po aplikácii Depotocínu inj. Spofa v ranom puerpériu oviec. Vet. Med. 36:607-618

KRAJNIĆÁKOVÁ, M., BEKEOVÁ, E., MARAČEK, I., HENDRICHOVSKÝ,V. 1992: Zmeny hmotnosti vaječníkov a počty povrchových folikulov po aplikácii Depotocínu inj. Spofa v puerperálnom období bahníc. Živ. výroba 37:385-391

KRAJNIČĆKOVÁ, M.. BEKEOVÁ, E., MARAČEK, I., HENDRICHOVSKÝ, V. 1994: Koncentrácie cholesterolu, celkových lipidov a progesterónu v puerperálnom období bahníc. Živ. výroba 39:1035-1040

KRAJNIĆÁKOVÁ, M., BEKEOVÁ, E., MARAČEK, I., HENDRICHOVSKÝ, V. 1995: Biometrické parametre vaječníkov oviec a ich zmeny po aplikácii Depotocínu inj. Spofa v puerperálnom období. Slov. Vet. Čas. 5: $245-247$

KUDLÁČ, E., VLČEK, Z.1970: Klinické změny na pohlavním ústrojí a obsah baktérií v děloze krav po normálním porodu. Vet. Med. 15:11 -19

McDONALD, L. E. 1980: Veterinary endocrinology and reproduction. Philadelphia, Lea and Febiger.

WHYMAN, D., MOORE, R. W. 1980: Effects of PMSG and the prostaglandin F-2 alpha analogue cloprostenol on superovulation, fertilization and egg transport in the ewe. J. Reprod. Fertil. 60:267-272

Address for correspondence:

Doc. MVDr. J. Danko, CSc.

Department of Anatomy

University of Veterinary Medicine

Komenského 73

04181 Košice

Slovak Republic 
Plate I.

Danko J.: Changes in Ovarian... pp. 71-74

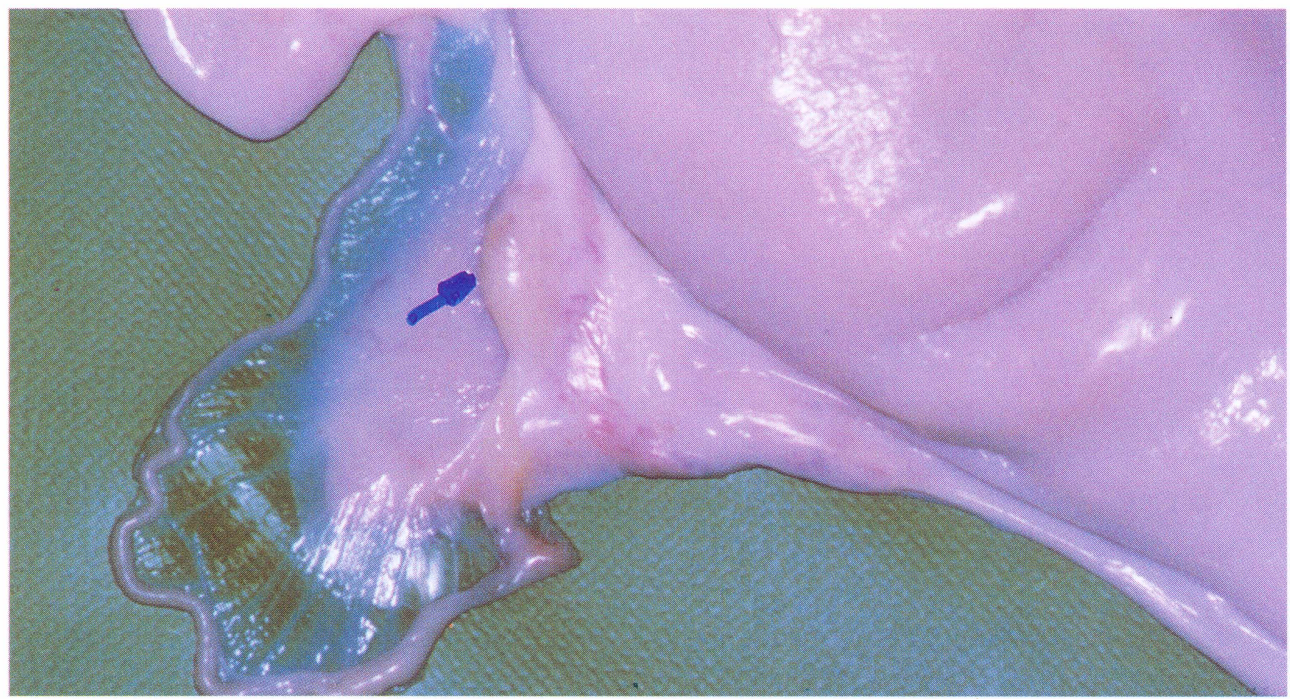

Fig. 1. The ovary of the ewe on $\mathrm{d} 7 \mathrm{p}$. p. There are small structures of pinhead size on its surface.

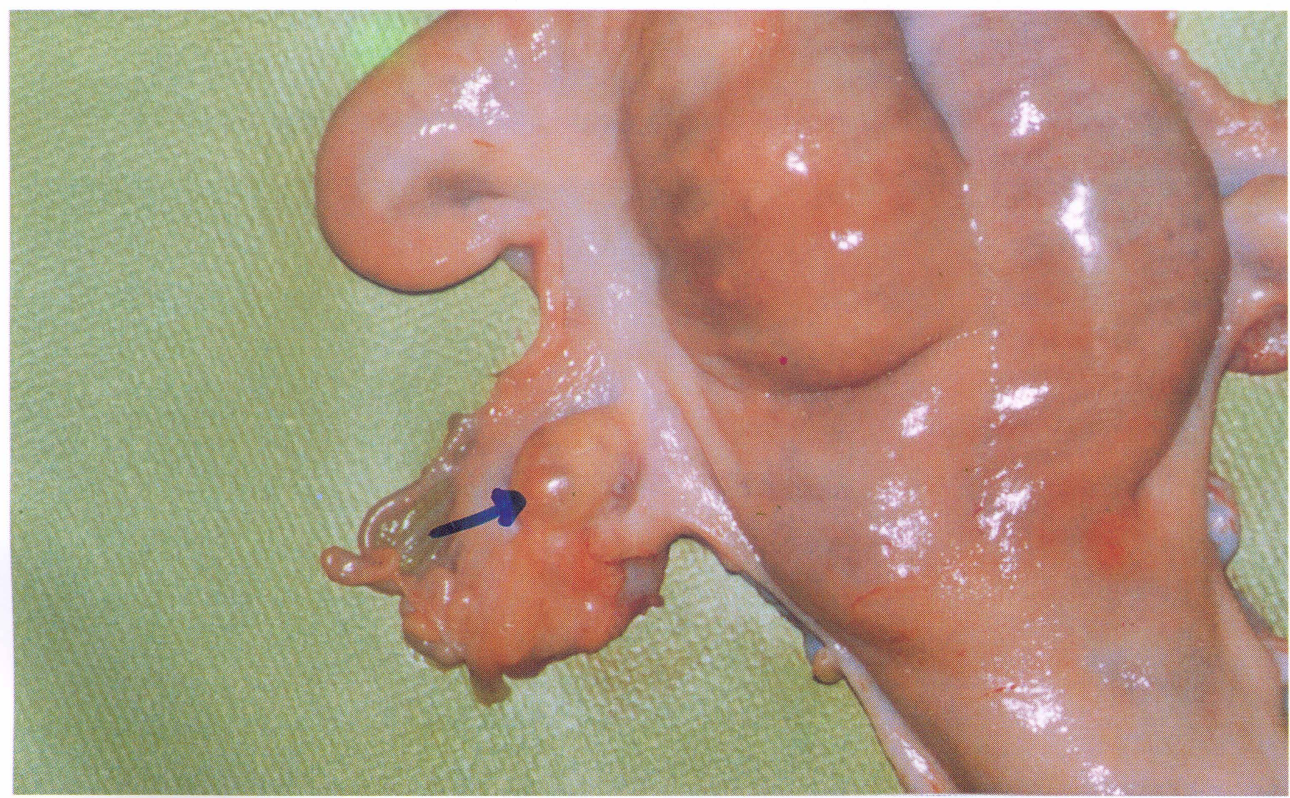

Fig. 2. The ipsilateral ovary of the hazelnut shape with occurrence of follicles larger than 4 and $2 \mathrm{~mm}$ on $\mathrm{d} 17 \mathrm{p}$. p. 